\title{
Perancangan Sistem Informasi Puskesmas Menggunakan PHP dan Database MySQL
}

\author{
Sukisno \\ Jurusan Teknik Informatika, Fakultas Teknik, Universitas Islam Syekh Yusuf, \\ Jl. Maulana Yusuf No.10 Tangerang Banten 15118, Indonesia \\ sukisno@unis.ac.id
}

\begin{abstract}
Abstrak. Teknologi informasi sekarang ini berkembang sangat pesat. Banyak bermunculan aplikasiaplikasi baru yang mendukung kebutuhan masyarakat. Tidak bisa dipungkiri lagi bahwa teknologi informasi sangat dibutuhkan oleh masyarakat untuk mempermudah pekerjaan, melancarkan transaksi, mencatat seluruh kegiatan dalam suatu bisnis proses suatu perusahaan. Pusat Kesehatan Masyarakat, disingkat Puskesmas, adalah organisasi fungsional yang menyelenggarakan upaya kesehatan yang bersifat menyeluruh, terpadu, merata, dapat diterima dan terjangkau oleh masyarakat, dengan peran serta aktif masyarakat dan menggunakan hasil pengembangan ilmu pengetahuan dan teknologi tepat guna, dengan biaya yang dapat dipikul oleh pemerintah dan masyarakat. Upaya kesehatan tersebut diselenggarakan dengan menitikberatkan kepada pelayanan untuk masyarakat luas guna mencapai derajad kesehatan yang optimal, tanpa mengabaikan mutu pelayanan kepada perorangan. Karena berhubungan dengan masyarakat luas, maka untuk transaksi yang ada di dalam sebuah Puskesmas harus dibuat cepat supaya efektif dan efisien. Berlatarbelakang kurang banyaknya aplikasi komputer yang ada di Puskesmas, maka peneliti melakukan perancangan, membuat desain, melakukan coding, testing dan implementasi terhadap aplikasi yang dibuat. Aplikasi ini bertujuan untuk merancang sistem informasi layanan di Puskesmas, menyimpan data sebagai master data, mencatat seluruh kegiatan business process yang ada di Puskesmas.
\end{abstract}

Kata kunci: Puskesmas, Kesehatan Masyarakat, Sistem Informasi

\begin{abstract}
Information technology is now growing very rapidly. Many emerging new applications that support the needs of the community. Can not be denied again that information technology is needed by the community to facilitate the work, transact the transaction, record all activities in a business process a company. The Center for Public Health, abbreviated as Puskesmas, is a functional organization that organizes health efforts that are comprehensive, integrated, equitable, acceptable and affordable by the community, with active participation of the community and use the results of the development of appropriate science and technology, by government and society. Health efforts are organized with emphasis on services for the wider community to achieve optimal health degree, without neglecting the quality of service to individuals. Because it deals with the wider community, then for transactions that exist in a Puskesmas should be made quickly to be effective and efficient. Background of the lack of computer applications available in the Puskesmas, the researchers design, design, coding, testing and implementation of applications made. This application aims to design service information system at Puskesmas, store data as master data, record all business process activities that exist in Puskesmas.
\end{abstract}

Keywords: Puskesmas, Public Health, Information Systems

\section{Pendahuluan}

Teknologi informasi sekarang ini berkembang sangat pesat. Banyak bermunculan aplikasi-aplikasi baru yang mendukung kebutuhan masyarakat. Tidak bisa dipungkiri lagi bahwa teknologi informasi sangat dibutuhkan oleh masyarakat untuk mempermudah pekerjaan, melancarkan transaksi, mencatat seluruh kegiatan dalam suatu bisnis proses suatu perusahaan.

Kebutuhan manusia salah satunya adalah kesehatan, dimana kesehatan tersebut merupakan modal utama untuk dapat melakukan aktifitas seharihari. Dalam peneltian ini akan merancang aplikasi yang akan digunakan di Puskesmas. Sistem informasi ini terintegrasi jadi satu kesatuan program yang sangat mudah digunakan oleh user yang ada di Puskesmas tersebut.

Sebelum melangkah ke penelitian lebih lanjut, peneliti akan menjelaskan secara singkat tentang Puskesmas. Pusat Kesehatan Masyarakat, disingkat Puskesmas, adalah organisasi fungsional yang menyelenggarakan upaya kesehatan yang bersifat menyeluruh, terpadu, merata, dapat diterima dan terjangkau oleh masyarakat, dengan peran serta aktif masyarakat dan menggunakan hasil pengembangan 
ilmu pengetahuan dan teknologi tepat guna, dengan biaya yang dapat dipikul oleh pemerintah dan masyarakat. Upaya kesehatan tersebut diselenggarakan dengan menitikberatkan kepada pelayanan untuk masyarakat luas guna mencapai derajad kesehatan yang optimal, tanpa mengabaikan mutu pelayanan kepada perorangan. Puskesmas merupakan unit pelaksana teknis kesehatan di bawah supervisi Dinas Kesehatan Kabupaten/Kota.Secara umum, mereka harus memberikan pelayanan preventif, promotif, kuratif sampai dengan rehabilitatif baik melalui upaya kesehatan perorangan (UKP) atau upaya kesehatan masyarakat (UKM). Puskesmas dapat memberikan pelayanan rawat inap selain pelayanan rawat jalan. Hal ini disepakati oleh puskesmas dan dinas kesehatan yang bersangkutan. Perawat memberikan pelayanan di masyarakat, puskesmas biasanya memiliki subunit pelayanan seperti puskesmas pembantu, puskesmas keliling, posyandu, pos kesehatan desa maupun pos bersalin desa (polindes)

Pusat Kesehatan Masyarakat (Puskesmas) adalah salah satu sarana pelayanan kesehatan masyarakat yang amat penting di Indonesia. Puskesmas adalah unit pelaksana teknis dinas kabupaten/kota yang bertanggungjawab menyelenggarakan pembangunan kesehatan di suatau wilayah kerja (Depkes, 2011). Fungsi Puskesmas yatiu pelayanan medik dasar yang lebih mengutamakan pelayanan,kuratif dan rehabilitatif dengan pendekatan individu dan keluarga pada umumnya melalui upaya rawat jalan dan rujukan (Depkes, 2007).

Karena berhubungan dengan masyarakat luas, maka untuk transaksi yang ada di dalam sebuah Puskesmas harus dibuat cepat supaya efektif dan efisien. Berlatarbelakang kurang banyaknya aplikasi komputer yang ada di Puskesmas, maka peneliti melakukan perancangan, membuat desain, melakukan coding, testing dan implementasi terhadap aplikasi yang dibuat. Aplikasi ini bertujuan untuk merancang sistem informasi layanan di Puskesmas, menyimpan data sebagai master data, mencatat seluruh kegiatan business process yang ada di Puskesmas.

\section{Metodologi}

Penelitian ini menggunakan metode RAD (Rapid Application Development). Rapid application development atau rapid prototyping adalah model proses pembangunan perangkat lunak yang tergolong dalam teknik incremental (bertingkat). RAD menekankan pada siklus pembangunan pendek, singkat, dan cepat. Waktu yang singkat adalah batasan yang penting untuk model ini. Rapid application development menggunakan metode iteratif (berulang) dalam mengembangkan sistem dimana working model (model bekerja) sistem dikonstruksikan di awal tahap pengembangan dengan tujuan menetapkan kebutuhan (requirement) user dan selanjutnya disingkirkan. Working model digunakan kadang-kadang saja sebagai basis desain dan implementasi sistem final.
Rapid Application Development (RAD) adalah strategi siklus hidup yang ditujukan untuk menyediakan pengembangan yang jauh lebih cepat dan mendapatkan hasil dengan kualitas yang lebih baik dibandingkan dengan hasil yang dicapai melalui siklus tradisional (Mc Leod, 2002). RAD merupakan gabungan dari bermacam-macam teknik terstruktur dengan teknik prototyping dan teknik pengembangan joint application untuk mempercepat pengembangan sistem atau aplikasi (Whitten dan Bentley, 2004). Dari definisi-definisi konsep RAD ini, dapat dilihat bahwa pengembangan aplikasi dengan menggunakan metode RAD ini dapat dilakukan dalam waktu yang relatif lebih cepat.

Pemaparan konsep yang lebih spesifik lagi dijelaskan oleh Pressman dalam bukunya, "Software Engineering: A Practition's Approach". Ia mengatakan bahwa RAD adalah proses model perangkat lunak inkremental yang menekankan siklus pengembangan yang singkat. Model RAD adalah sebuah adaptasi "kecepatan tinggi" dari model waterfall, di mana perkembangan pesat dicapai dengan menggunakan pendekatan konstruksi berbasis komponen. Jika tiap-tiap kebutuhan dan batasan ruang lingkup projek telah diketahui dengan baik, proses RAD memungkinkan tim pengembang untuk menciptakan sebuah "sistem yang berfungsi penuh" dalam jangka waktu yang sangat singkat. Dari penjelasan Pressmanini (2012), satu perhatian khusus mengenai metodologi RAD dapat diketahui, yakni implementasi metode RAD akan berjalan maksimal jika pengembang aplikasi telah merumuskan kebutuhan dan ruang lingkup pengembangan aplikasi dengan baik.

Sedangkan menurut Kendal (Kendall dan Kendall, 2010), RAD adalah suatu pendekatan berorientasi objek terhadap pengembangan sistem yang mencakup suatu metode pengembangan serta perangkat-perangkat lunak. RAD bertujuan mempersingkat waktu yang biasanya diperlukan dalam siklus hidup pengembangan sistem tradisional antara perancangan dan penerapan suatu sistem informasi. Pada akhirnya, RAD sama-sama berusaha memenuhi syarat-syarat bisnis yang berubah secara cepat.

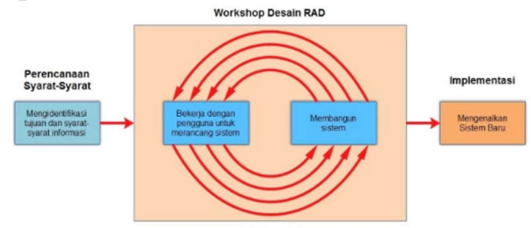

Gambar 1. Siklus RAD

Menurut Kendall, terdapat tiga fase dalam RAD yang melibatkan penganalisis dan pengguna dalam tahap penilaian, perancangan, dan penerapan. Adapun ketiga fase tersebut adalah requirements planning (perencanaan syarat-syarat), RAD design workshop (workshop desain RAD), dan implementation (implementasi). Sesuai dengan metodologi RAD menurut Kendall, berikut ini adalah 
tahap-tahap pengembangan aplikasi dari tiap-tiap fase pengembangan aplikasi.

1. Requirements Planning (Perencanaan SyaratSyarat)

Dalam fase ini, pengguna dan penganalisis bertemu untuk mengidentifikasikan tujuan-tujuan aplikasi atau sistem serta untuk megidentifikasikan syarat-syarat informasi yang ditimbulkan dari tujuan-tujuan tersebut. Orientasi dalam fase ini adalah menyelesaikan masalah-masalah perusahaan. Meskipun teknologi informasi dan sistem bisa mengarahkan sebagian dari sistem yang diajukan, fokusnya akan selalu tetap pada upaya pencapaian tujuan-tujuan perusahaan (Kendall dan Kendall, 2010).

2. RAD Design Workshop (Workshop Desain RAD) Fase ini adalah fase untuk merancang dan memperbaiki yang bisa digambarkan sebagai workshop. Penganalisis dan dan pemrogram dapat bekerja membangun dan menunjukkan representasi visual desain dan pola kerja kepada pengguna. Workshop desain ini dapat dilakukan selama beberapa hari tergantung dari ukuran aplikasi yang akan dikembangkan. Selama workshop desain RAD, pengguna merespon prototipe yang ada dan penganalisis memperbaiki modul-modul yang dirancang berdasarkan respon pengguna. Apabila sorang pengembangnya merupakan pengembang atau pengguna yang berpengalaman, Kendall menilai bahwa usaha kreatif ini dapat mendorong pengembangan sampai pada tingkat terakselerasi (Kendall dan Kendall, 2010).

3. Implementation (Implementasi)

Pada fase implementasi ini, penganalisis bekerja dengan para pengguna secara intens selama workshop dan merancang aspek-aspek bisnis dan nonteknis perusahaan. Segera setelah aspek-aspek ini disetujui dan sistem-sistem dibangun dan disaring, sistem-sistem baru atau bagian dari sistem diujicoba dan kemudian diperkenalkan kepada organisasi (Kendall dan Kendall, 2010).

Metode pengembangan sistem RAD relatif lebih sesuai dengan rencana pengembangan aplikasi yang tidak memiliki ruang lingkup yang besar dan akan dikembangkan oleh tim yang kecil. Namun, RAD pun memiliki kelebihan dan kekurangannya sebagai sebuah metodologi pengembangan aplikasi. Berikut ini adalah kelebihan metodologi RAD menurut Marakas (Marakas, 2006):

1) Penghematan waktu dalam keseluruhan fase projek dapat dicapai.

2) RAD mengurangi seluruh kebutuhan yang berkaitan dengan biaya projek dan sumberdaya manusia.

3) RAD sangat membantu pengembangan aplikasi yang berfokus pada waktu penyelesaian projek.
4) Perubahan desain sistem dapat lebih berpengaruh dengan cepat dibandingkan dengan pendekatan SDLC tradisional.

5) Sudut pandang user disajikan dalam sistem akhir baik melalui fungsi-fungsi sistem atau antarmuka pengguna.

6) RAD menciptakan rasa kepemilikan yang kuat di antara seluruh pemangku kebijakan projek.

Sedangkan, mengacu pada pendapat Kendall ${ }^{[9]}$, maka dapat diketahui bahwa kekurangan penerapan metode RAD adalah sebagai berikut:

1) Dengan metode $\mathrm{RAD}$, penganalisis berusaha mepercepat projek dengan terburu-buru.

2) Kelemahan yang berkaitan dengan waktu dan perhatian terhadap detail. Aplikasi dapat diselesaikan secara lebih cepat, tetapi tidak mampu mengarahkan penekanan terhadap permasalahanpermasalahan perusahaan yang seharusnya diarahkan.

3) RAD menyulitkan programmer yang tidak berpengalaman menggunakan prangkat ini di mana programmer dan analyst dituntut untuk menguasai kemampuan-kemampuan baru sementara pada saat yang sama mereka harus bekerja mengembangkan sistem.

\section{Hasil dan Pembahasan}

Sesuai dengan metode yang dipakai yaitu Rapid Apllication Development (RAD) maka dalam penelitian ini akan dibahas mengenai Requirement Planning, Desain dan Implementation.

1. Tahapan Rencana Kebutuhan (Requirement Planning)

1) Kebutuhan Hardware
a. Processor
: Intel ${ }^{\circledR}$ Core i3 CPU
b. Memory : $1 \mathrm{~GB}$
c. Harddisk : $320 \mathrm{~GB}$
d. Printer : Epson L360
e. Keyboard : Logitech K120
f. Mouse : Logitech Wireless M165

2) Kebutuhan Software

a. Sistem Operasi : Windows 10 Enterprise 64-bit

b. XAMPP Versi 3.2.1

c. Browser Chrome

d. Microsoft Visio 2013

3) Kebutuhan Input

a. Data Dokter

b. Data Tindakan dan Tarif

c. Data Tindakan Laboratorium dan Tarif

d. Data Perusahaan Penjamin

e. Data Obat

f. Data Transaksi

g. Data Payment

h. Data User

4) Kebutuhan Informasi

a. Laporan Tindakan

b. Laporan Tindakan Laboratorium

c. Laporan Transaksi Resep Dokter

d. Laporan Daftar Pasien 
e. Laporan Pembayaran

2. Tahap Desain Sistem (Workshop Desain)

1) Membuat Use Case Diagram

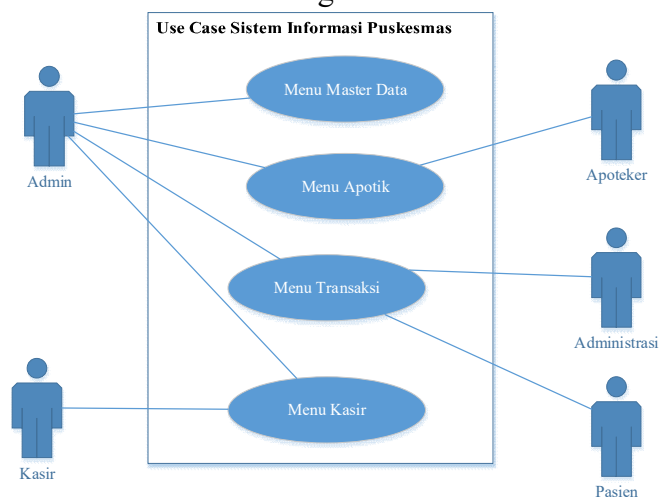

Gambar 2. Use Case Diagram Sistem Informasi Puskesmas

2) Membuat Activity Diagram

a. Activity Diagram Apoteker

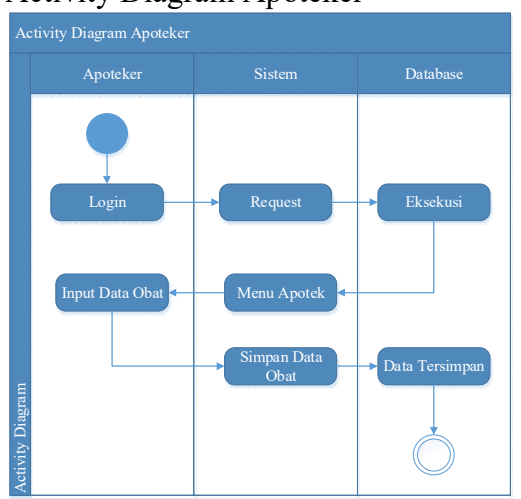

Gambar 3. Activity Diagram Apoteker

b. Activity Diagram Kasir

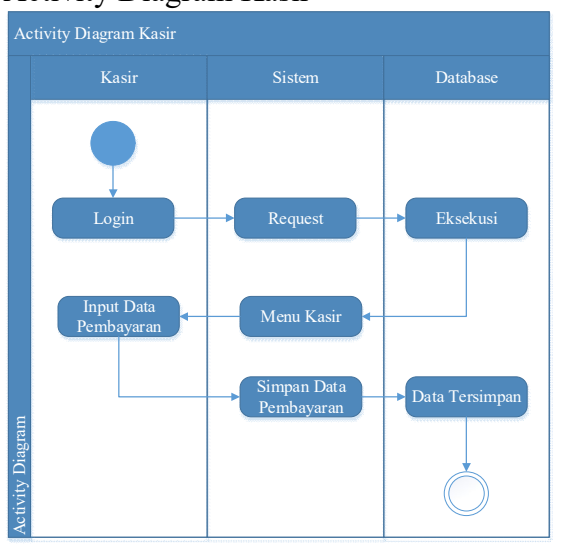

Gambar 4. Activity Diagram Kasir

c. Activity Diagram Pasien

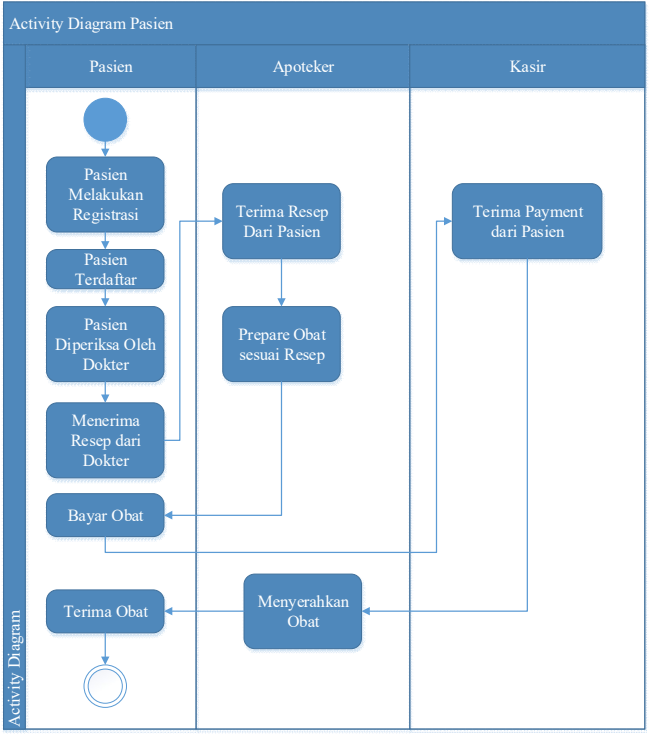

Gambar 5. Activity Diagram Pasien

3) Membuat Sequence Diagram

a. Sequence Diagram Input Data Pasien

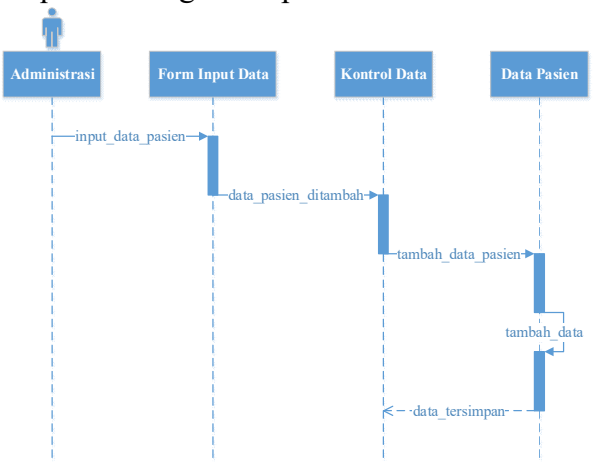

Gambar 6. Sequence Diagram Input Data Pasien

b. Sequence Diagram Pasien

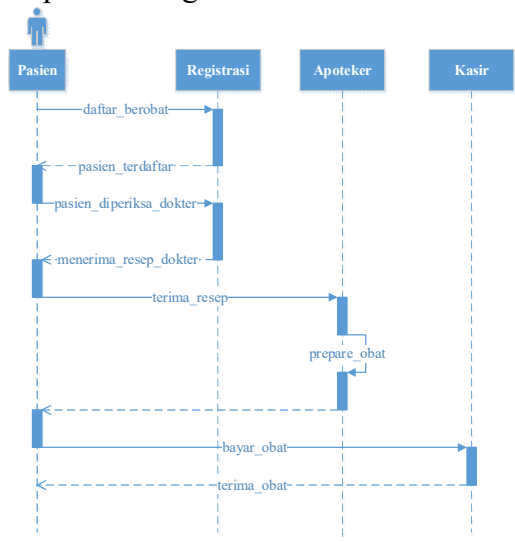

Gambar 7. Sequence Diagram Pasien 
4) Membuat Class Diagram

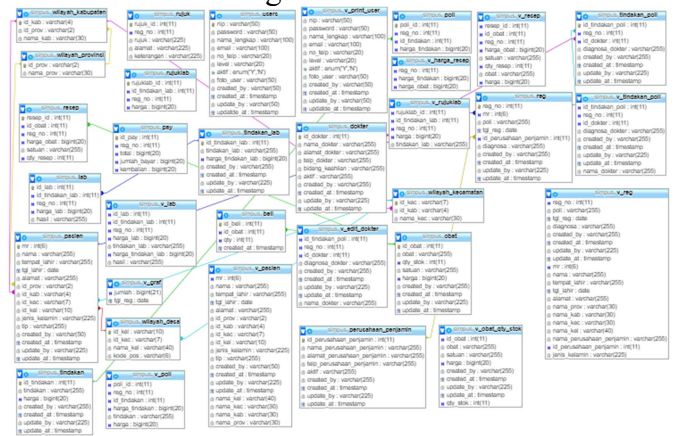

Gambar 8. Class Diagram Sistem Informasi Puskesmas

3. Tahap Implementasi

Tahap implementasi adalah mengimplementasikan hasil rancangan aplikasi yang telah dibuat. Implementasi tersebut menggunakan XAMPP versi 3.2.1, Software text editor dan Microsoft Visio 2013.

a. Perangkat Keras (Hardware)

Processor : Intel ${ }^{\circledR}$ Core i3 CPU

Memory : $1 \mathrm{~GB}$

Harddisk : $320 \mathrm{~GB}$

Printer : Epson L360

Keyboard : Logitech K120

Mouse : Logitech Wireless M165

b. Perangkat Lunak (Software)

Sistem Operasi : Windows 10 Enterprise 64-bit

XAMPP Versi 3.2.1

Browser Chrome

Microsoft Visio 2013

c. Pengujian Sistem

Pada tahap pengujian dilakukan dengan menggunakan blackbox testing. Cara pengujiannya adalah dengan menjalankan aplikasi sistem informasi puskesmas kemudian melihat outputnya apakah sesuai dengan hasil yang diharapkan. Berikut ini salah satu contoh pengujian dengan blackbox.

Tabel 1. Pengujian Blacbox Testing

\begin{tabular}{ccllr}
\hline No. & \multicolumn{1}{c}{ Test Case } & \multicolumn{1}{c}{ Output } & \multicolumn{1}{c}{ Actor } & Hasil \\
\hline 1 & Pilih Menu Login & Tampil Menu Login & Admin, Kasir, Apoteker & Sesuai \\
\hline 2 & Pilih Menu Master & Tampil Menu Master & Admin & Sesuai \\
\hline 3 & Pilih Menu Apotik & Tampil Menu Apotik & Admin, Apoteker & Sesuai \\
\hline 4 & Pilih Menu Transaksi & Tampil Menu Transaksi & Admin, Kasir & Sesuai \\
\hline 5 & Pilih Menu Kasir & Tampil Menu Kasir & Admin, Kasir & Sesuai \\
\hline
\end{tabular}

\section{Kesimpulan}

1. Melalui penerapan metode RAD (Rapid Application Development) dapat menghasilkan sistem informasi puskesmas sesuai dengan yang diharapkan.

2. Dengan adanya aplikasi sistem informasi puskesmas, dapat mempercepat proses transaksi dan semua data dapat tersimpan dengan baik dalam database MySQL.

3. Penyelesaian tahapan dalam perancangan sistem informasi puskesmas mengikuti tahapan yang ada dalam model RAD (Rapid Application Development).

\section{Daftar Pustaka}

Departmen Kesehatan. (2007). Direktorat Jendral Bina pelayanan Medik Standar Minimal Pelayanan Kesehatan Gigi Puskesmas.

Departmen Kesehatan. (2011). Sistem Kesehatan. Jakarta.

http://fannynurrizky06.blogspot.co.id/2013/11/rapidapplication-development-rad.html di access 4 Januari 2018 Jam 14.17WIB

https://id.wikipedia.org/wiki/Pusat Kesehatan Mas yarakat di access 4 Januari $20 \overline{18}$ Jam 00.15 WIB

https://piyaneo.wordpress.com/2014/05/10/rapidapplication-development-rad// di access 4 Januari 2018 Jam 14.35WIB

Kendall, J.E. \& Kendall, K.E. (2010). Analisis dan Perancangan Sistem. Jakarta: Indeks.

Marakas, G.M. 2006. System Analysis Design: an Active Approach. New York: Mc.Graw-Hill.

Mc.,Leod, R. Jr. 2002. System Development: A Project Management Approach. New York: Leigh Publishing LLC.

Pressman, R.S. 2012. Rekayasa Perangkat Lunak: Pendekatan Praktisi. Yogyakarta: Penerbit Andi.

Whitten, J.L. \& Bentley, L.D. (2004). System Analysis \& Design Methods: Sixth Edition. New York: Mc.Graw-Hill. 